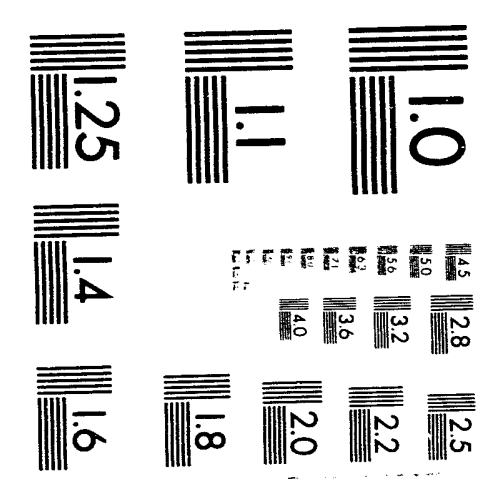



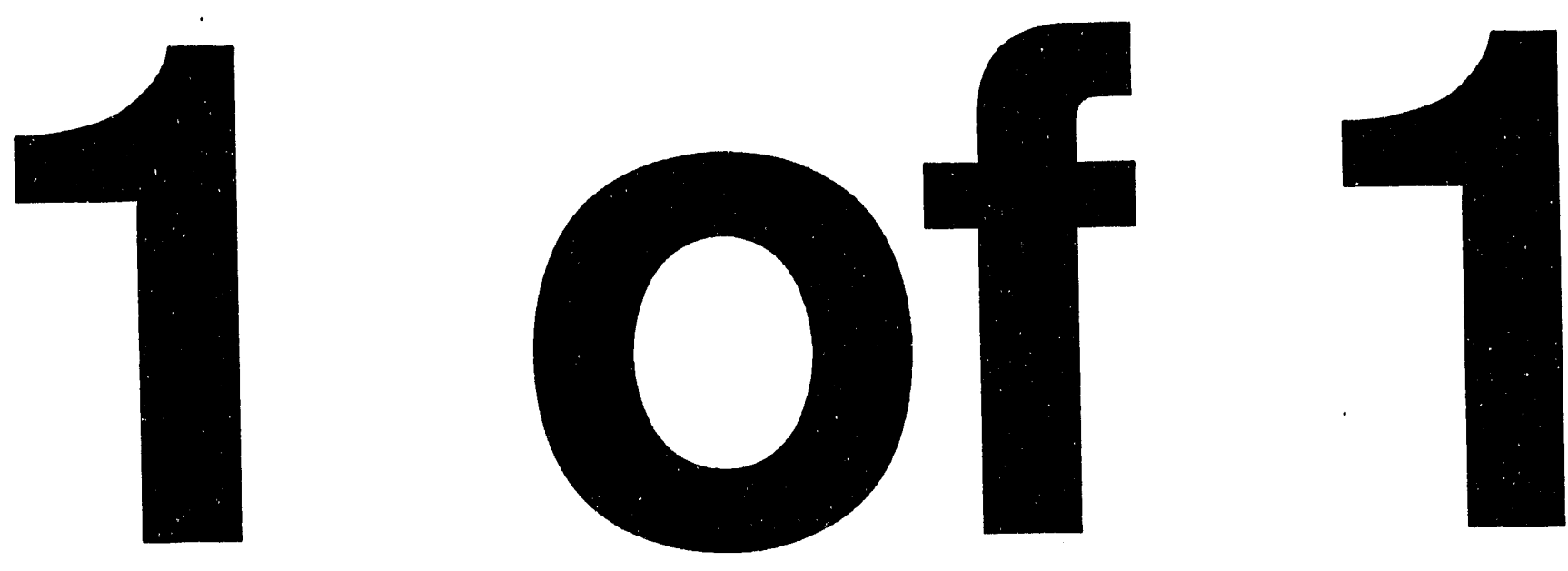


\section{UGE OF A COMPREHENSIVE CALCULATION "GAUNTLET" APPROACH FOR IMPROVED CONTAMINANTS TRANSPORT MODELING AT THE F AND H AREA SEEPAGE BASINS (U)}

by

B. B. Looney

Westinghouse Savannah River Company

Savannah River Site

Aiken, South Carolina 29808

J. S. Haselow, WSRC

W. W. Pidcoe, WSRC

C. M. Lewis, WSRC

P. F. Anderson, GeoTrans, Inc.

C. P. Spalding, GeoTrans Inc.

This paper was prepared in connection with work done under the above contract number with the U. S.

Department of Energy. By acceptance of this paper, the publisher and/or recipient acknowledges the U. S. Government's right to retain a nonexclusive, royalty-free license in and to any copyright covering this paper, along with the right to reproduce and to authorize others to reproduce all or part of the copyrighted paper. 
WSRC-MS-93-582

\section{USE OF A COMPREHENSIVE CALIBRATION "GAUNTLET" APPROACH FOR IMPROVED CONTAMINANT TRANSPORT MODELING AT THE F AND H AREA SEEPAGE BASINS (U)}

by

B. B. Looney ${ }^{1}$, J. S. Haselow ${ }^{1}$, W. W. Pidcoe ${ }^{1}$, C. M. Lewis ${ }^{1}$, P. F. Anderson ${ }^{2}$ and C. P. Spalding 2

1 Westinghouse Savannah River Company Savannah River Site Aiken SC 29808

2 GeoTrans Inc 46050 Manekin Plaza, Suite 100 Sterling VA 20166

The information contained in this article was developed during the course of work under Contract No. DE-AC09-88SR18035 with the U.S. Department of Energy. By acceptance of this paper, the publisher and/or recipient acknowledges the U.S. Government's right to retain a nonexclusive, royalty free license in and to any copyright covering this paper along with the right to reproduce, and to authorize others to reproduce all or part of the copyrighted paper. 
Use of a Comprehensive Calibration "Gauntlet" Approach for Improved Contaminant Transport Modeling at the $F$ and $H$-Area Seepage Basins

\author{
B. B. Looney*, J. S. Haselow*, W. W. Pidcoe*, C. M. Lewis*, P. F. Andersen**, and C. P. \\ Spalding**
}

*Westinghouse Savannah River Company, Aiken, SC

**GeoTrans Inc., Sterling, VA

\begin{abstract}
Many types of facility and monitoring data have been collected to support operation, closure and environmental restoration of the F and $\mathrm{H}$-Area Seepage Basins at the Savannah River Site. Based on the various types of data, we developed contaminant transport models to allow projection of contaminant releases and comparison of restoration alternatives. The modeling was performed in the following three stages:

1. postulation of a conceptual model of the flow and transport system

2. development of a simplified analytical model based on a transfer function

3. development of a numerical model
\end{abstract}

A key feature of the work was use of both traditional data sources and calibration targets such as heads, geological data and pump test results, and non-traditional data sources and calibration targets, such as plume arrival times and shapes, contaminant release rates, and surface water concentrations. Throughout the process, the intermediate and final results were compared to all of the various data types and the earlier modeling stages. The result was a calibration "gauntlet" with explicit criteria for refinement and acceptance of the final model. Failure to match at any step within the gauntlet necessitated appropriate reformulation or modification of the model and rechecking for acceptable matches.

This modeling approach successfully produced a clear and concise description of the flow and transport (the conceptual model), an intuitive tool that was useful for rapid scoping calculations (the transfer function model), and a robust numerical model that allowed evaluation of a wide range of potential groundwater remediations. Using stepwise development, incorporating all available data, and using appropriate acceptance criteria, resulted in a high level of internal consistency and overall defensibility.

\title{
Introduction
}

The F and $\mathrm{H}$-Area Seepage Basins received large volumes of dilute aqueous wastes from the 1950 s through 1988 . Over the years, the relatively mobile constituents in the wastewater migrated into the water table and then downgradient to Four Mile Branch. Breakthrough of tritium and nitrate was measured in the downgradient stream in the early $1960 \mathrm{~s}$. The shape of the plumes as they evolved, the shape of the arrival front, and the average transit time (i.e., the magnitude of radioactive decay during flow) all indicated the presence of large-scale preferential flow paths in the downgradient system. Sediment cores beneath the basins and groundwater/mineralogy data provided information about the magnitude of sorption and transport of the various contaminants.

In the baseline case, water enters the system from infiltration (and formerly the basins) and exits to the downgradient wetlands along Four Mile Branch. Site-specific studies of rainfall, runoff, and evapotranspiration were used to estimate the magnitude of water flow and the approximate size range of a postulated remediation system.

At this point, preliminary numerical models and a transfer function model were generated to facilitate a more quantitative evaluation of potential remediations. The transfer function approach assumes that the flow system may be entirely described using a mathematical equation to transform the contaminant input record into a contaminant output prediction. Such models typically simplify complex flow and transport processes into a function that has only a few 
parameters. The parameters are estimated using a period of record for inputs and outputs. High quality measurements of tritium input to the $\mathrm{F}$ and $\mathrm{H}$-Area Basins every year of operation are available; similar measurements of output to Four Mile Branch beginning in 1958 (H Area) and 1967 (F Area) are also available. The transfer function model was useful for modeling relatively simple remediation scenarios.

A numerical model, consistent with the conceptual and analytical models, was developed to allow quantitative assessment of more complex remediation schemes. In particular, the numerical simulation was needed to simulate the effect of upgradient or downgradient barriers, and for placement of recovery wells to maximize recovery and minimize wetland impacts.

\section{Geology and Hydrology}

As shown on Figure 1, the F and H Area Seepage Basins are located in the center of SRS between two streams, Upper Three Runs to the north and Fourmile Branch to the south. Recharge to the grouncwater in this area is primarily due to infiltration of rainwater (rainfall minus runoff and evar;otranspiration). Groundwater moves downward and laterally, draining to the nearby streams. As expected, there is a groundwater divide in the shallow water-bearing zones. North of the divide, flow is toward Upper Three Runs and its tributaries and south of the divide, flow is toward Fourmile Branch and its tributaries. In the vicinity of the basins, the shallow groundwater discharges to Fourmile Branch.

Measurements (e.g., flow and contaminant concentrations) in surface waters and in groundwater downgradient of these facilities have been performed from the 1950s through the present.

Additionally, examination of cores from drilling and boring and geological descriptions of the area have been performed during this period. Most of the flow to Fourmile branch occurs in the upper two water-bearing layers, a water table zone and a semiconfined zone. A leaky aquitard (clayey zone) is present between these zones. Within these zones, there are areas with higher and lower permeability. This structure controls the water flow rates, the contaminant plume shape, and the contaminant arrival times and locations in the downgradient surface water. As expected, vertical water flow in these plumes follows a curved path downward near the source and then upward into the draining surface water. Surface water monitoring stations in the vicinity of these facilities have been used to determine the groundwater and contaminant flux to Fourmile Branch and to associate the fluxes in the various stream reaches to the upgradient facilities.

\section{Operational History/Conceptual Model}

The $\mathrm{F}$ and $\mathrm{H}$ Area Seepage Basins received large volumes of dilute aqueous wastes from $i$ late 1950s through 1988. The primary dissolved constituents in the wastewater were hydrogen ions (low pli), nitrate, and sodium. The wastewater also contained relatively low concentrations of other chemical constituents (e.g., mercury, cadmium, and lead). The radioactive constituent with the highest activity in the wastewater was tritium; other relatively mobile radionuclides in the wastewater included ${ }^{90}$ Strontium, ${ }^{99}$ Technetium, and ${ }^{129}$ Iodine. A large anount of operational data, geology studies, groudwater and plume chemistry data, ecology characterizations, hydrology and modeling studies are available to support decision-Inaking for these facilities. Observations in the sediments, groundwater, wetlands, and streams underlying and downgradient of the $\mathrm{F}$ and $\mathrm{H}$ Area Seepage Basins are indicative of the behavior of contaminants under the substantively perturbed conditions during basin operations (see Fenimore and Horton 1968 \& 1972; Christensen and Gordon 1983; Killian et al. 1987a \& 1987b; Loney et al. 1988; Haselow et al. 1990; Corbo et al. 1985; Dixon and Rogers 1992):

- During basin operations, relatively large volumes of water were added to the subsurface, maximizing the driving force $t()$ move contaminants through the underlying sediments into the groundwater and to the downgradient hydrologic boundary (primarily Fourmile Branch).

- Breakthrough of tritium and nitrate was measured in the downgradient wetlands in the early $1960 \mathrm{~s}$. 
- The shapes of the groundwater plumes indicate that there are permeable sediments or large scale heterogeneities (or both) in the downgradient system that result in relatively rapid flow.

- The bulk chemistry in the contaminant plume has been altered (increases ionic strength, reduced $\mathrm{pH}$, etc.). This tends to reduce the partitioning of metal ions to the soil because of competition with hydrogen ion for exchange sites. Also, the perturbation in bulk chemistry results in a more aggressive solution chemistry and enhances the leaching of constituents from the sediments in the flow path. The chemical shift would also tend to generate and stabilize colloidal solids that are a documented transport vector for small amounts of a normally sorbed contaminant.

- Sediment cores from the basins indicated that a large fraction of the contaninants nornally assumed to have relatively high distribution coefficients are held up in the sediments above the water table, despite the bulk chemistry of the plume.

- Following basin closure, mobile contaminant fluxes (e.g., tritium) to the seep line have begun to decline as these contaminants flush from the system.

The facility installation and operation records and the environmental monitoring data forn the basis for the modeling activities. The modeling was performed in the following three stages:

1. postulation of a conceptual model of the flow and transport system

2. development of a simplified analytical model based on a transfer function

3. development of a numerical model

The conceptual model is outlined in the listing above; the subsequent modeling activities are addressed below.

\section{Transfer Function Modeling}

To facilitate quantitative projection of tritium fluxes and to provide initial estimates of the impacts of corrective action implementation, a straightforward analytical model of contaminant transport from the seepage basins to the downgradient strean was developed. The approach used in the model is an intuitive "transfer function" similar to that developed by Jury (1982) for describing transport of agricultural contaminants. The transfer function model assumes that the flow system, in this case the flow path between the basins and the seep line, may be entirely described using a mathematical equation to transform the contaminant input record into a contaminant output prediction. The mathematicai transfornation used is selected based on its consistency with measured data and the assumed governing chemical and physical processes. Such models typically simplify the complex processes governing transport into a function that has only a few parameters. Specific flow and dispersion relationships and permeability variations caused by channels or barriers are not explicitly described. Instead, the transfer function model estimates the average and extreme behavior of the contaminant based on the field measured distribution of travel times. Such models are good predictive tools if the following occurs:

- sufficient historical data on input and output flux are available

- historical input and output can be simply related

- perturbations to the system are describable and relatively small

Measurements of tritium input to the $\mathrm{F}$ and $\mathrm{H}$-Area Seepage Basins every year of operation are available; similar measurements of tritum flux to Fourmile Branch beginning in 1958 (H Area) and 1967 (F Area) are also available. As discussed below, a log normal transit time assumption appears reasonable for both areas, providing a simple mathematical function. Applying the model to relatively simple scenarios as a screening tool provides results that are useful to project fluxes into the future. Additionally, the transfer function molel results were compared to updated numerical modeling of these areas, calibrated using all of the historical flux, plume shape, geology, and water level data to provide documentation of final corrective action decisions. The 
numerical model was used to refine tritium flux projections and to extend the analysis to more complex remediation system analysis.

In the transfer function model for the $\mathrm{F}$ and $\mathrm{H}$-Area Seepage Basins, each year's tritium flux to the basins is allowed to reach the seep line as described by a probability density function. The flux contribution from a particular year $(t)$ to the seepline in a future year $(t+d t)$ is equal to the original input flux times the value of the transfer function for a time shift of $\mathrm{dt}$. The total area under the probability density function is 1.0 (for nondecaying contaminants) so that all of the contaminant input to the system in any year leaves the system over time. By superposition, the predicted contaminant output history is simply the sum of all of the various years' contributions. For radioactive constituents, the radioactive decay constant is incorporated into the transfer function to account for contaminant loss during the transit. A large number of investigators have examined subsurface hydraulic conductivity and flow variations (Jury et al. 1982 \& 1987; White et al. 1984 \& 1986; Molz et al. 1986; Nielson et al. 1973; Van de Pol et al. 1977; Biggar and Nielson 1976; Sharma et al. 1980; Smith et al. 1985). These studies suggest that the appropriate transfer function is a $\log$ normal distribution. This distribution has a peak (near the $\ln$ mean transit time) and is skewed to the right. As shown below, the distribution as a function of time is entirely defined by the $\mu$ and $\sigma$.

$$
F_{t}=\frac{1}{\sigma(\sqrt{2 \pi}} \exp \left(-0.5\left(\frac{\ln (t)-\mu}{\sigma}\right)^{2}\right)
$$

Figure 2 shows an example transfer function generated by the model. Both of the curves shown (with and without decay) are calculated for each run. This provides a quality assurance check and docuis.ents the amount of contaminant lost by radioactive decay during transit. As described above, the flux of contaminant to the strean in any year is simply the sum of the estimated contributions from all of the previous years disposals to the facility.

$$
\text { stream flux } \left.(\text { year } j)=\sum_{i=1957}^{j} \text { basin flux (year } i\right) x F_{j-i}
$$

The historical tritium input measurements to the $\mathrm{F}$ and $\mathrm{H}$-Area Seepage Basins and the historical tritium flux measurements to Fourmile Branch downgradient of these basins are shown in Table 1. The values in Table 1 serve as the calibration targets for estimating $\mu$ and $\sigma$ for each area. Based on minimizing the sum of the squares of the differences between model predictions and the measurements, the following transfer function parameters were selected ( $t$ in years):

H Area: $\mu=2.0$ and $\sigma=2.0$

F Area: $\mu=2.6$ and $\sigma=0.8$

Figure 3 shows an example calibration for $\mathrm{H}$ Area. Overall, the transfer function models reasonably matched the conceptual model (facility operation and site monitoring data). Further, the approach was judged to be adequate for simple contaminant release projections, remediation scenario evaluation, and to assist in numerical model development.

\section{Numerical Modeling}

A numerical model, consistent with the conceptual and analytical models, was developed to allow quantitative assessment of more complex remediation schemes. In particular, the numerical simulation was needed to simulate the effect of upgradient or downgradient barriers, and for placement of recovery wells to maximize recovery and minimize wetland impacts.

During the generation of the numerical model, the final calibration gauntlet was generated (Figure 4). A key feature of this approach was use of toth traditional and nontraditional calibration targets. Traditional targets included groundwater levels from 382 monitoring wells, observed mounding data during basin operation, groundwater discharge measurements, and others. Nontraditional targets included plume arrival times and shapes, levels of contamination in a lower aquifer, and contaminant flux rate (o) Fourmile Branch. Throughout the process, the intermediate and final 
results were compared to the various data types and earlier modeling stages. The resulting calibration gauntlet had explicit criteria for acceptance. Failure to match at any step within the gauntlet necessitated appropriate reformulation or modification of the model and rechecking for acceptable matches through the entire gauntlet. As an example, Figure 5 shows the calculated tritium flux from the $\mathrm{H}$-Area Seepage Basin to Fourmile Branch for the numerical model and transfer function model. The resulting calibrated numerical model was used to evaluate a wide range of corrective action scenarios, including infiltration reduction, groundwater pump-treatreinjection, and ungradient or downgradient barriers. The model was also used to optimize pumping rates and recovery/reinjection well placement for the pump-and-treat scenarios.

\section{Conclusion}

Using stepwise development, incorporating all available data, and using appropriate acceptance criteria resulted in a high level of internal consistency and overall defensibility. This approach successfully produced a clear and concise description of the flow and transport (the conceptual model), an intuitive tool that was useful for rapid scoping calculations (the transfer function model), and a robust numerical model that allowed evaluation of a wide range of potential groundwater remediations. Based on the results, we recommend early development of a calibration gauntlet (including all types of available site-specific data) to help assure the quality of groundwater and contaminant transport modeling activities.

\section{Acknowledgement}

The information contained in this article was developed by Westinghouse Savannah River Company during the course of work under contract No. DE-AC09-89SR18035 with the U. S. Department of Energy.

\section{References}

Biggar, J. W. and D. R. Nielson, 1987. Spatial variability of the leaching characteristics of a field soil, Water Resources Research, 23, 1876-1886.

Corbo, P., M. V. Kantello, and C. B. Fliermans, 1985. Basin Characterization Summary: Analytical Results, Database Management, and Quality Assurance Results for Analysis of Soil Cores form the F- and H-Area Seepage Basins, DPST-85-921, E. I. du Pont de Nemours and Co., Savannah River Laboratory, Aiken, SC 29808.

Christensen, E. J. and D. E. Gordon, 1983. Technical Summary of Groundwater Quality Protection Program at the Savannah River Plant, DPST-83-829, E. I. du Pont de Nemours and Co., Savannah River Laboratory, Aiken, SC 29808.

Dixon, K. L. and V. A. Rogers, 1992. Results of the First Quarter Tritium Survey of the F and HArea Seeplines: May 1992. WSRC-TR-92-304, Westinghouse Savannah River Company, Aiken, SC 29808.

Fenimore, J. W. and J. H. Horton, Jr., 1968. Influence of High Level Waste Salts on Movement of Strontium and Cesium in Savannah River Plant Soil, DP-1124, E. I. du Pont de Nemours and Co., Savannah River Laboratory, Aiken, SC 29808.

Fenimore, J. W. and J. H. Horton, Jr., 1972. Operating History and Environmental Effects of Seepage Basins in Chemical Separations Areas of the Savannah River Plant, DPST-72-548, E. I. du Pont de Nemours and Co., Savannah River Laboratory, Aiken, SC 29808.

Haselow, J. S., M. Harris, B. B. Looney, N. V. Halverson, and J. B. Gladden, 1990. Analysis of Soil and Water at the Four Mile Creek Seepline near the F \& H Areas of SRS WSRC-RP90-0591, Westinghouse Savannah River Company, Savannah River Laboratory, Aiken, SC 29808.

Jury, W. A., 1982. Simulation of solute transport using a transfer function model, Water Resources Research, 18, 363-368. 
Jury, W. A, L. H. Stolzy, and P. Shouse, 1982. A field test of the transfer function model for predicting solute transport, Water Resources Research, 22, 243-247.

Killian, T. H., N. L. Kolb, P. Corbo, and I. W. Marine, 1987b. Environmental Information Document: H-Area Seepage Basins, DPST-85-706, E. I. du Pont de Nemours and Co., Savannah River Laboratory, Aiken, SC 29808.

Looney, B. B., J. E. Cantrell, and J. R. Cook, 1988. Sampling and Analysis of Surface Water in the Vicinity of the F- and H- Area Seepage Basins, DPST-88-229, E. I. du Pont de Nemours and Co., Savannah River Laboratory, Aiken, SC 29808.

Molz, F. J., O. Guven, J. G. Malville, R. D. Crocker, and K. T. Matteson, 1986. Perfornance, analysis and simulation of a two well tracer test at the Mobile Site, Water Resources Research, 22, 1031-1037.

Nielson, D. R., J. W. Bigger, and K. T. Erh, 1973. Spatial variability of field measured soil properties, Hilgardia, 42, 215-260.

Sharma, M. L., G. A. Gander, and C. G. Hunt, 1980. Spatial variability of infiltration in a watershed, Jour. Hydrology, 45, 101-122.

Smith, M. S., G. W. Thomas, R. E. White, and D. Ritonga, 1985. Transport of Escherichia coli through intact and disturbed columns of soil, Jour. Environmental Quality, 14, 87-91.

Van de Pol, R. M., P. J. Wierenga, and D. R. Nielson, 1977. Solute movement in a field soil, Soil Science Soc. of America Jour., 41, 10-13.

White, R. E., G. W. Thomas, and M. S. Smith, 1984. Modeling water flow through undisturbed cores using a transfer function model derived from tritium and chloride transport, Jour. Soil Science, 35, 159-168.

White, R. E., J. S. Dyson, R. A. Haigh, W. A. Jury, and G. Sposito, 1986. A transfer function model of solute transport through soil, 2: illustrative applications, Water Resources Research, 21, 447-457. 
Table 1. Historical Tritium Flux Data for the F and $H$ Area Seepage Basins

\begin{tabular}{|c|c|c|c|c|}
\hline \multirow[b]{2}{*}{ year } & \multicolumn{2}{|c|}{ H Area Basins groundwater system } & \multicolumn{2}{|c|}{ F Area Basins groundwater system } \\
\hline & $\begin{array}{l}\text { input to basins } \\
\text { (Ci) }\end{array}$ & $\begin{array}{l}\text { flux to stream } \\
\text { (Ci) }\end{array}$ & $\begin{array}{c}\text { input to basins } \\
\text { (Ci) }\end{array}$ & $\begin{array}{l}\text { flux to stream } \\
\text { (Ci) }\end{array}$ \\
\hline 1957 & 5920 & nd & 880 & nd \\
\hline 1958 & 5500 & 400 & 0 & nd \\
\hline 1959 & 5607 & 800 & 5836 & nd \\
\hline 1960 & 4366 & 1600 & 8341 & nd \\
\hline 1961 & 11613 & 2000 & 10297 & nd \\
\hline 1962 & 12706 & 1700 & 18050 & nd \\
\hline 1963 & 8240 & 2700 & 17157 & nd \\
\hline 1964 & 6430 & 4700 & 21569 & nd \\
\hline 1965 & 13135 & 5600 & 16151 & nd \\
\hline 1966 & 17018 & 4600 & 19992 & nd \\
\hline 1967 & 7609 & 3000 & 11938 & 2600 \\
\hline 1968 & 20678 & 2900 & 14002 & 2887 \\
\hline 1969 & 11015 & 3500 & 11679 & 2589 \\
\hline 1970 & 21107 & 4400 & 10944 & 2592 \\
\hline 1971 & 14160 & 9500 & 4766 & 2299 \\
\hline 1972 & 15176 & 5400 & 7051 & 3485 \\
\hline 1973 & 19891 & 6800 & 11941 & 4185 \\
\hline 1974 & 8118 & 5700 & 7512 & 3176 \\
\hline 1975 & 10144 & 6800 & 3690 & 2080 \\
\hline 1976 & 15663 & 4300 & 6041 & 2653 \\
\hline 1977 & 8824 & 4500 & 3922 & 3657 \\
\hline 1978 & 8891 & 5500 & 4763 & 3454 \\
\hline 1979 & 7511 & 6700 & 5970 & 2160 \\
\hline 1980 & 8021 & 5300 & 5323 & 1507 \\
\hline 1981 & 13377 & 4200 & 7578 & 1106 \\
\hline 1982 & 9134 & 4900 & 4540 & 2770 \\
\hline 1983 & 12952 & 6500 & 7482 & 2568 \\
\hline 1984 & 11955 & 8020 & 9344 & 2320 \\
\hline 1985 & 12414 & 4560 & 9895 & 2690 \\
\hline 1986 & 26677 & 7360 & 10232 & 1800 \\
\hline 1987 & 13599 & 5630 & 13162 & 2760 \\
\hline 1988 & 9851 & 3980 & 3142 & 3330 \\
\hline 1989 & 0 & 4600 & 0 & 4443 \\
\hline 1990 & 0 & 1900 & 0 & 3570 \\
\hline 1991 & 0 & 1810 & 0 & 5750 \\
\hline 1992 & 0 & $1500 \mathrm{est}$ & 0 & 4000 est \\
\hline $10-$ & & & & \\
\hline
\end{tabular}




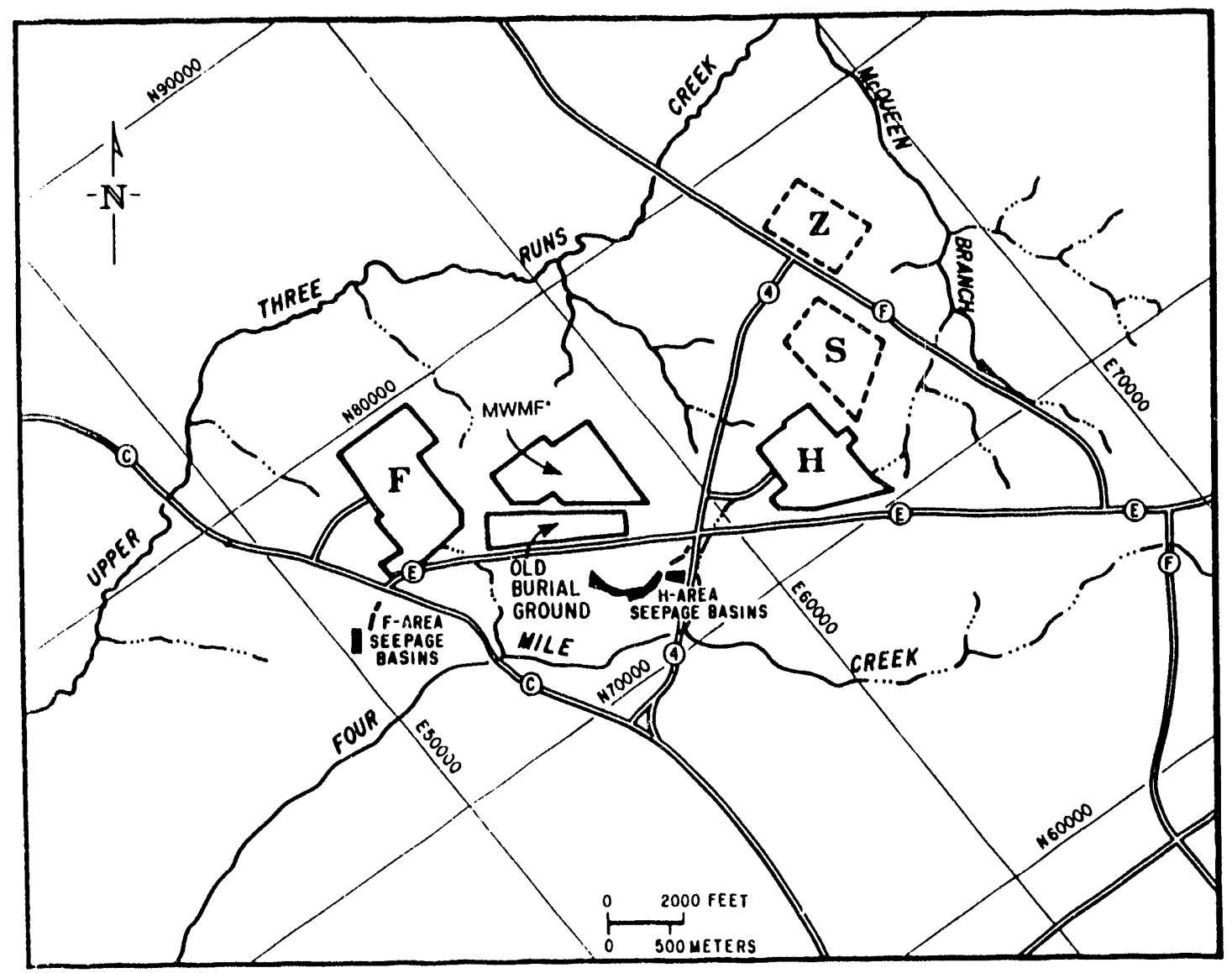

- MWMF - Mixed Waste Management Facility and the associated Low Level Radioactive Waste Disposal Facility

Figure 1. Map of Study Area

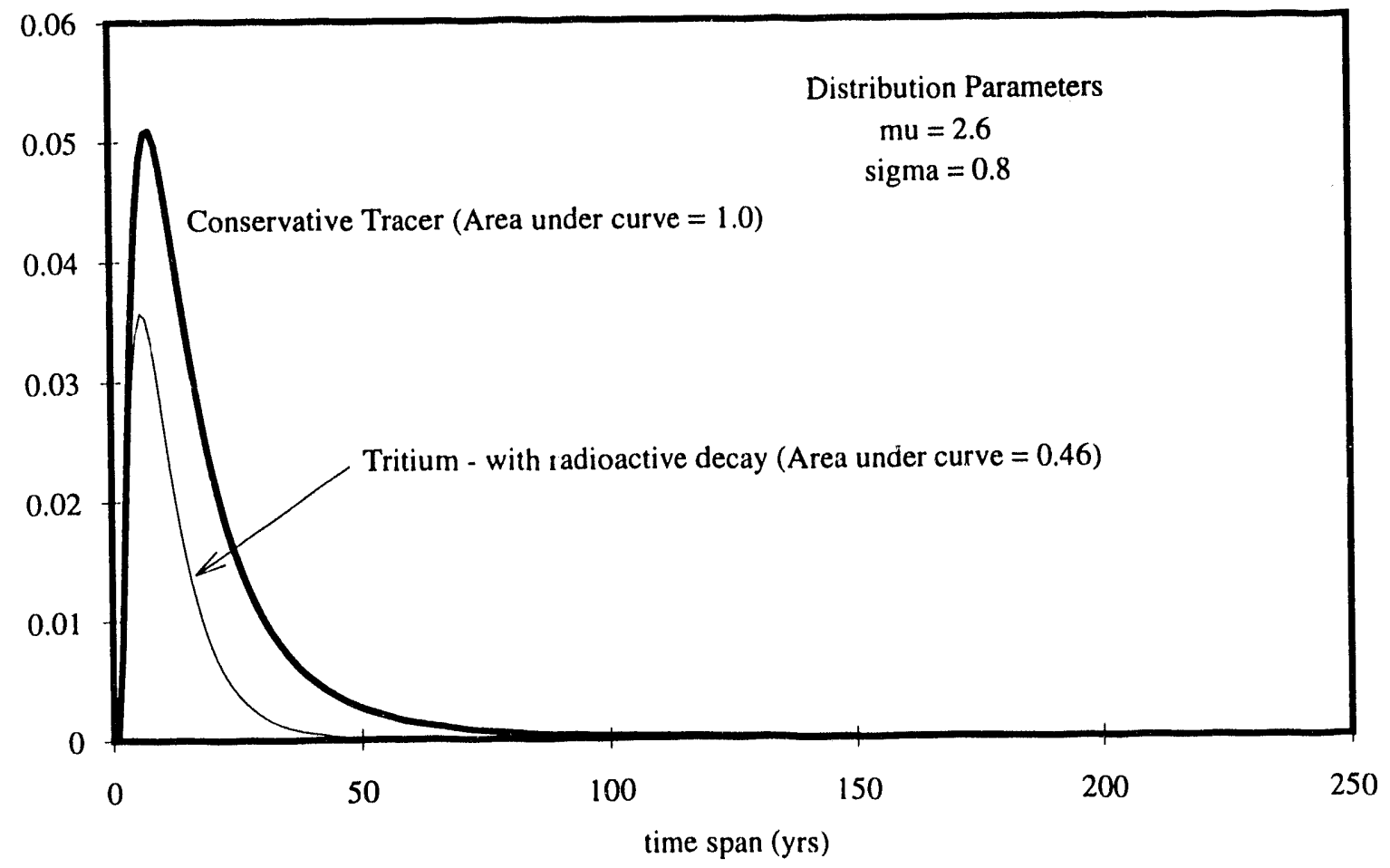

Figure 2. Transfer Function Example - relative flux at seep line from one years input to basins 


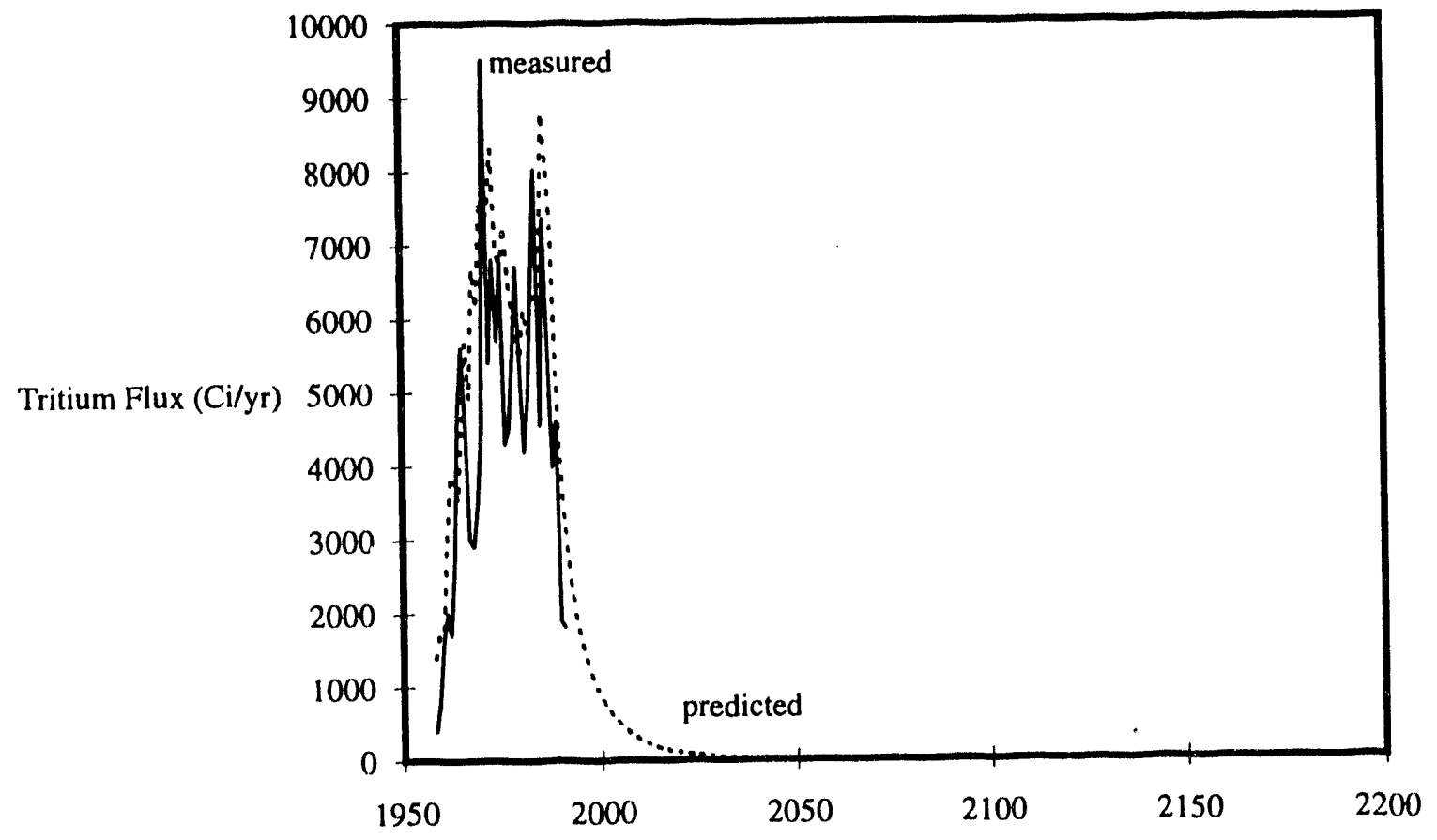

Figure 3. Example Transfer Function Calibration - H Area Seepage Basins 


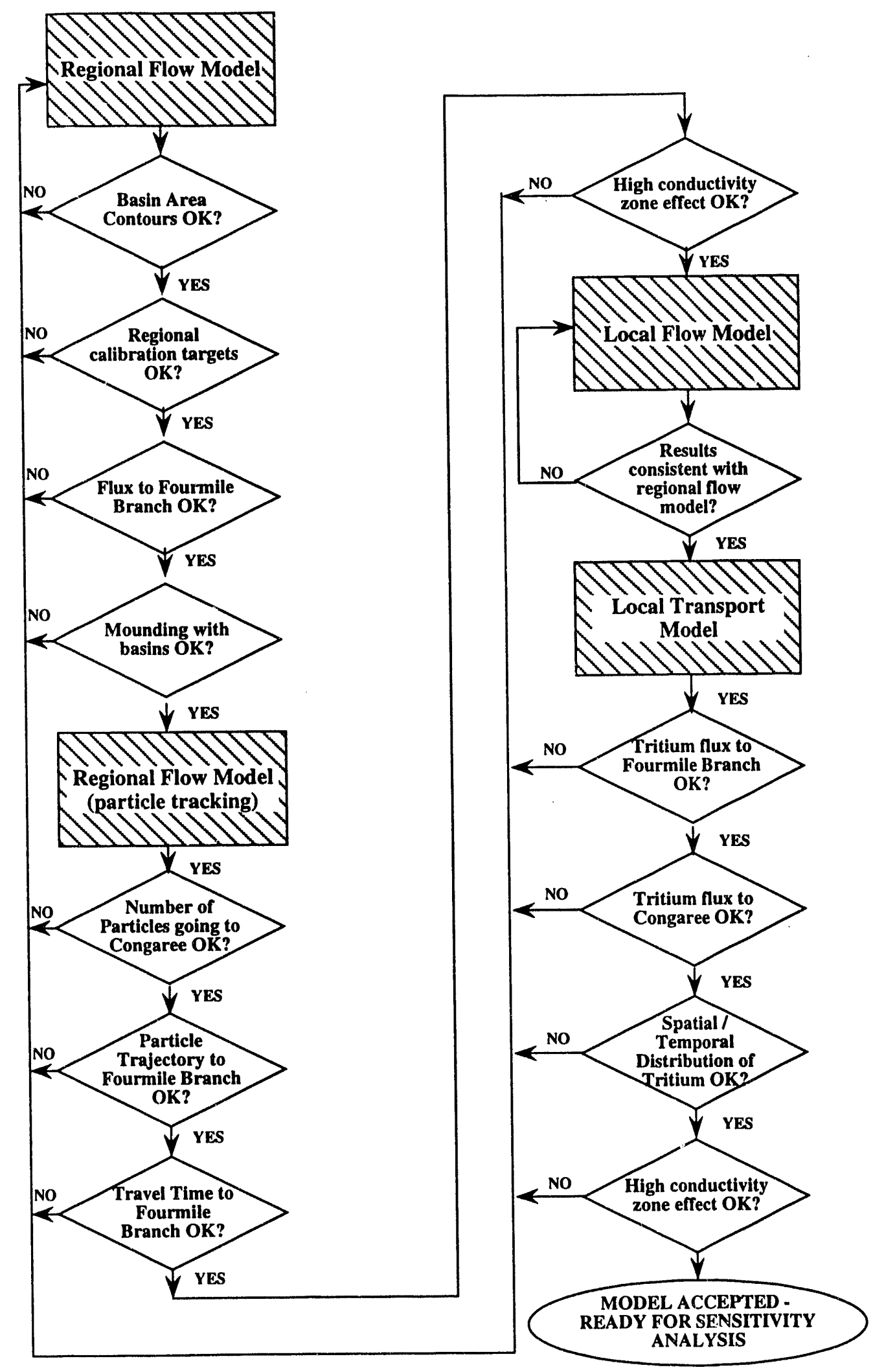

Figure 4. Final Calibration Gauntlet Used in Study 
Figure . Comparison of Measurements, Transfer Function Predictions and Numerical Model

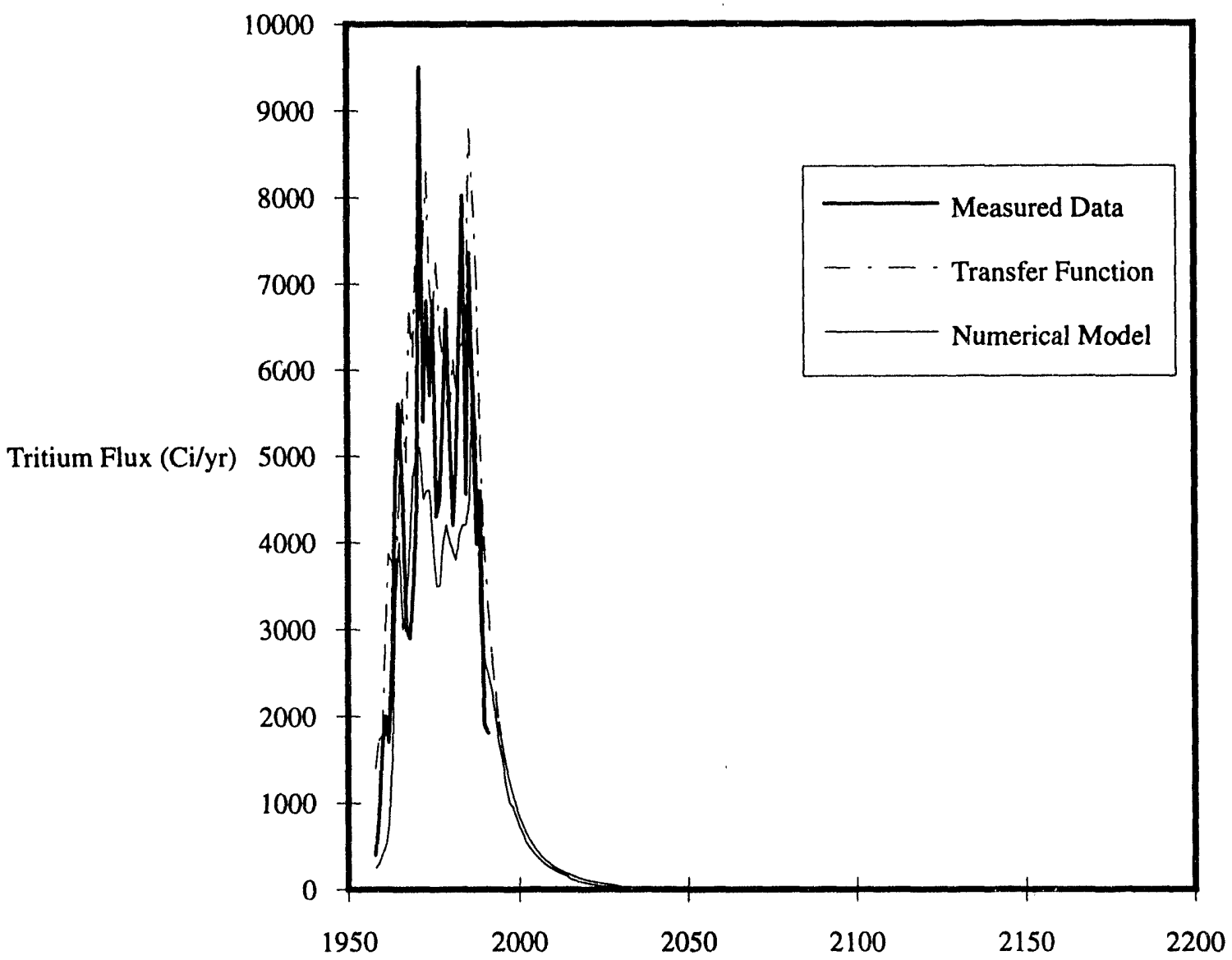

Figure 5. Example Calibration - Comparison of Field Data, Transfer Function Model and Numerical Model 

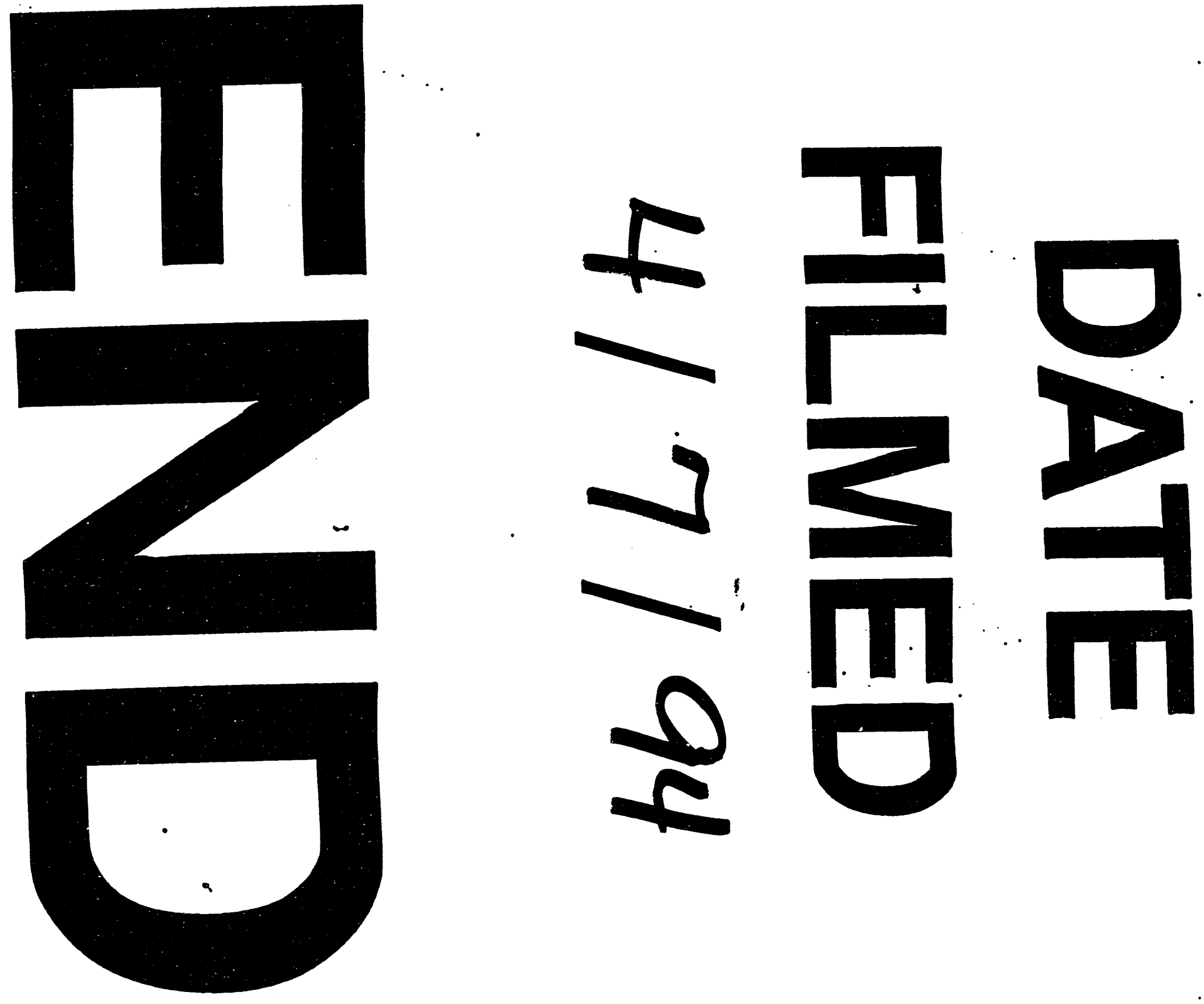

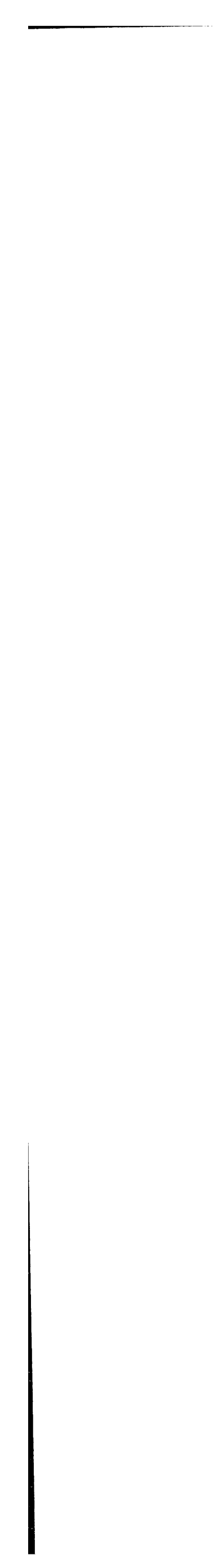